\title{
LL-D49194 ANTIBIOTICS, A NOVEL FAMILY OF ANTITUMOR AGENTS: TAXONOMY, FERMENTATION AND BIOLOGICAL PROPERTIES
}

\author{
W. M. Maiese, D. P. Labeda ${ }^{\dagger}$, J. Korshalla, N. Kuck, A. A. Fantini, \\ M. J. Wildey, J. Thomas and M. GreENSTEIN \\ Medical Research Division, American Cyanamid Company, Lederle Laboratories, \\ Pearl River, New York 10965, U.S.A. \\ 'Culture Collection Laboratory, USDA-NRRL, \\ Peoria, Illinois 61604, U.S.A.
}

(Received for publication August 8, 1989)

\begin{abstract}
A novel family of antitumor antibiotics, designated LL-D49194, was isolated from the fermentation broth of an actinomycete strain identified as Streptomyces vinaceus-drappus. LL-D49194 $\alpha_{1}$ and $\beta_{2}$ were active against Gram-positive and inactive against Gram-negative bacteria in vitro. The $\beta_{1}$ component was not active against either Gram-positive or Gram-negative bacteria. These antibiotics exhibited significant in vivo activities against several murine tumors, albeit with differing potencies.
\end{abstract}

In the course of our search for novel antitumor agents produced by microorganisms, a culture designated LL-D49194 was isolated from a soil sample and was found to produce a new family of antitumor compounds (Fig. 1). This paper describes the taxonomy of the producing culture, fermentation and biological activities of these agents.

\section{Materials and Methods}

Microorganism

Culture LL-D49194 was isolated from a soil sample collected in La Encanada, Peru. This culture was

Fig. 1. Chemical structures of LL-D49194 $\alpha_{1}, \beta_{1}$ and $\beta_{2}$.

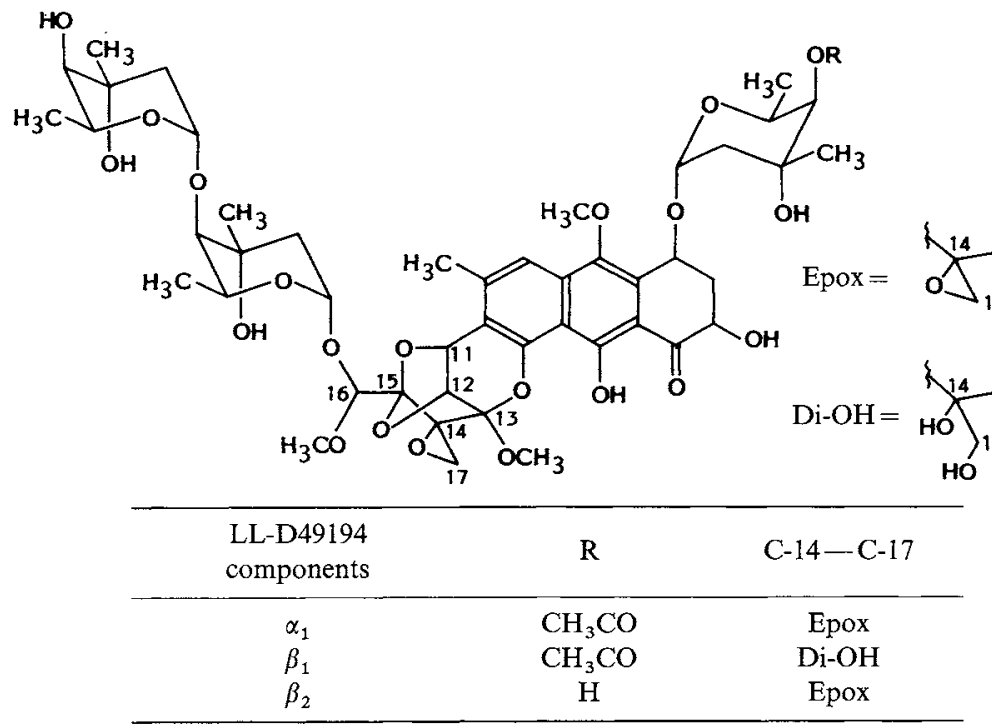


deposited with the Northern Regional Research Center's Culture Collection Laboratory under the accession No. NRRL 15735.

Taxonomic Studies

The taxonomic studies were carried out as described by the International Streptomyces Project (ISP) ${ }^{1)}$ and GORDON et $\mathrm{al}^{2)}$. For the evaluation of cultural characteristics, the strains were incubated for $14 \sim 31$ days at $28^{\circ} \mathrm{C}$. Cell wall composition was analyzed by the methods of LECHEVALIER and LECHEVALIER ${ }^{3)}$.

Media and Fermentation

Culture LL-D49194 was stored as a frozen suspension at $-70^{\circ} \mathrm{C}$ in growth medium. A $1.5-\mathrm{ml}$ aliquot of thawed suspension was used to inoculate $100 \mathrm{ml}$ of seed medium (yeast extract $0.5 \%$, beef extract $0.3 \%$, Tryptose $0.5 \%$, glucose $1.0 \%$ and $\mathrm{CaCO}_{3} 0.1 \%$ ) in a $500-\mathrm{ml}$ Erlenmeyer flask. This seed inoculum was incubated on a rotary shaker $\left(5 \mathrm{~cm}\right.$ orbit) at $200 \mathrm{rpm}, 28^{\circ} \mathrm{C}$, for 48 hours and was then added to a 3 liter fermenter containing 1 liter of seed medium. Following 48 hours incubation (aeration: $1 \mathrm{v} / \mathrm{v} / \mathrm{m}, 450 \mathrm{rpm}$ ), the contents of this fermenter were inoculated into 30 liters of seed medium (molasses $2.0 \%$, peptone $0.5 \%$, glucose $1.0 \%$ and $\mathrm{CaCO}_{3} 0.1 \%$ ) in a 41 -liter fermenter. This culture was grown at $32^{\circ} \mathrm{C}$ for up to 48 hours (aeration: $1 \mathrm{v} / \mathrm{v} / \mathrm{m}, 350 \mathrm{rpm}$ ). The contents from this fermenter were inoculated into a 410 -liter fermenter containing 300 liters of seed medium (aeration: $0.75 \mathrm{v} / \mathrm{v} / \mathrm{m}, 250 \mathrm{rpm}$ ). After 48 hours growth at $32^{\circ} \mathrm{C}$, these 300 liters were used to inoculate a production fermenter containing 3,000 liters of medium (glucose $3.0 \%$, molasses $1.0 \%$, peptone $0.5 \%$ and $\mathrm{CaCO}_{3} 0.1 \%$ ). This fermentation was carried out at $28^{\circ} \mathrm{C}$ for up to 150 hours (aeration: $0.66 \mathrm{v} / \mathrm{v} / \mathrm{m}, 450 \mathrm{rpm}$ ). The $\mathrm{pH}$ of the seed and production media used in these studies was adjusted to $6.8 \sim 7.0$ prior to sterilization. Microbial growth was determined by packed cell volume. Antibiotic production was monitored by the biochemical prophage induction assay (BIA $)^{4,5}$ and analytical HPLC ${ }^{6}$.

\section{Isolation and TLC/Bioautography}

The BIA active compounds produced by culture LL-D49194 were associated with the mycelium and were recovered by extracting the whole fermentation broth with ethyl acetate ${ }^{6}$. Antimicrobial and BIA activities on the TLC plates were detected by bioautography.

\section{Antibacterial Activity}

The in vitro antibacterial activities of the LL-D49194 antibiotics against a spectrum of Gram-positive and Gram-negative bacteria were determined by an agar dilution method employing Mueller-Hinton medium. The lowest concentration of antibiotic that inhibited growth of a bacterial strain after 18 hours of incubation at $35^{\circ} \mathrm{C}$ was recorded as the MIC.

\section{Antitumor Activity}

The antitumor activity of each component was determined in male $\mathrm{BDF}_{1}$ mice against $\mathrm{P} 388$ leukemia and B16 melanoma. The P388 leukemia test was initiated by ip injection of $10^{6}$ cells per mouse in $0.5 \mathrm{ml}$ of dilute ascitic fluid. For B16 melanoma, a $1 \mathrm{~g}$ portion of tumor was homogenized in $10 \mathrm{ml}$ of balanced salt solution, and a $0.5-\mathrm{ml}$ aliquot was implanted intraperitoneally into each mouse. The antibiotics were administered intraperitoneally days 1, 5 and 9 after initiation of the P388 test and by the same route on days 1 through 9 for B16. The antitumor activity was expressed as $\mathrm{T} / \mathrm{C}$ values (median survival time of the treated group/median survival time of the untreated group $\times 100$ ), with a value of $\geq 125$ being considered significant.

\section{Results}

\section{Taxonomic Studies of the Producing Culture}

Culture LL-D49194 was isolated from a soil sample collected in La Encanada, Peru. Examination of the culture grown at $28^{\circ} \mathrm{C}$ for $14 \sim 31$ days on various media revealed that spores were formed in coiled chains on aerial sporophores. The spores were ovoid $(0.4 \sim 0.5$ by $0.9 \sim 1.0 \mu \mathrm{m})$, and the surface of the 
mature spores was smooth when observed by scanning electron microscopy. A summary of the culture's growth characteristics on various media is presented in Tables $1 \sim 3$. Whole cell analysis showed that the strain contained the L,L-isomer of diaminopimelic acid, placing it in the type I cell wall group of LECHEVALIER et $a .^{7}{ }^{7}$. Utilization of carbon sources is summarized in Table 4. From the macromorphological, chemotaxonomic and physiological studies, it was concluded that culture LL-D49194 taxonomically resembles the reference strain of Streptomyces vinaceus-drappus and is designated as a strain of this species.

\section{Fermentation}

Culture LL-D49194 was grown in a 3,000-liter fermenter at $28^{\circ} \mathrm{C}$ for 150 hours. A typical time course for the production of the antitumor antibiotic is shown in Fig. 2. Antibiotic production started at

Table 1. Comparison of LL-D49194 with Streptomyces reference cultures.

\begin{tabular}{llll}
\multicolumn{1}{c}{ Culture } & Spore mass color & Soluble pigments & \multicolumn{1}{c}{ Reverse color } \\
\hline S. bottropensis NRRL 12051 & Light grayish yellow-brown & Reddish-brown & Brownish black \\
S. vinaceus-drappus NRRL 2363 & Light gray to pinkish gray & None & Moderate orange-yellow \\
LL-D49194 & Light gray to pinkish gray & None & Moderate orange-yellow \\
\hline
\end{tabular}

Table 2. Cultural characteristics of LL-D49194.

\begin{tabular}{|c|c|c|c|c|}
\hline Medium & $\begin{array}{l}\text { Amount of } \\
\text { growth }\end{array}$ & $\begin{array}{l}\text { Aerial mycelium } \\
\text { and/or spores }\end{array}$ & $\begin{array}{l}\text { Soluble } \\
\text { pigment }\end{array}$ & Reverse color \\
\hline $\begin{array}{l}\text { Glycerol - } \\
\text { asparagine agar }\end{array}$ & Good to moderate & $\begin{array}{l}\text { Slightly raised colonies } \\
\text { with white aerial } \\
\text { mycelia becoming } 264 \text {. } \\
\text { Light gray to } 10 . \\
\text { Pinkish gray in } \\
\text { sporulated areas }\end{array}$ & None & Light yellow \\
\hline $\begin{array}{l}\text { Hickey - Tresner } \\
\text { agar }\end{array}$ & Good & $\begin{array}{l}\text { Slightly raised colonies } \\
\text { with white aerial } \\
\text { mycelia becoming } 264 . \\
\text { Light gray to } 10 . \\
\text { Pinkish gray in } \\
\text { sporulated areas; } \\
\text { sporulation heavy }\end{array}$ & None & Yellowish brown \\
\hline $\begin{array}{l}\text { Inorganic saits - } \\
\text { starch agar }\end{array}$ & Good & $\begin{array}{l}\text { Relatively flat growth } \\
\text { with very heavy } \\
\text { sporulation, } 264 . \\
\text { Light gray }\end{array}$ & Brownish & Deep yellow \\
\hline Oatmeal agar & Moderate & $\begin{array}{l}\text { Flat powdery growth } \\
\text { with } 264 \text {. Light gray } \\
\text { to } 10 . \text { Pinkish gray } \\
\text { with } 265 . \text { Medium } \\
\text { gray patches }\end{array}$ & None & Yellowish white \\
\hline $\begin{array}{l}\text { Tomato paste- } \\
\text { oatmeal agar }\end{array}$ & Good & $\begin{array}{l}\text { Raised colonies with } \\
\text { white aerial mycelia } \\
\text { becoming } 264 \text {. Light } \\
\text { gray to } 10 . \text { Pinkish } \\
\text { gray where sporulated }\end{array}$ & Brownish & \\
\hline $\begin{array}{l}\text { Yeast extract - } \\
\text { malt extract } \\
\text { agar }\end{array}$ & Good & $\begin{array}{l}\text { Raised, ridged colonies } \\
\text { with white aerial } \\
\text { mycelia becoming } 10 . \\
\text { Pinkish gray in } \\
\text { sporulated areas }\end{array}$ & None & $\begin{array}{l}\text { Moderate } \\
\text { orange-yellow }\end{array}$ \\
\hline
\end{tabular}

a ISCC, National Bureau of Standard Centroid Color Charts, Publication 440, Washington, D.C., 1976. 
approximately $24 \sim 30$ hours after inoculation and reached maximum titers at approximately 120 hours.

\section{Antibacterial Activity}

The antibacterial activities of the $\alpha_{1}, \beta_{1}$ and $\beta_{2}$ components of LL-D49194 are shown in Table 5 . The $\alpha_{1}$ and $\beta_{2}$ components exhibited activity against Gram-positive bacteria with MIC values in the $\mu \mathrm{g} / \mathrm{ml}$ range. None of the three LL-D49194 components tested had activity against the Gram-negative bacteria. The $\beta_{1}$ antibiotic was essentially inactive against the test bacteria.

\section{Antitumor Activity}

The antitumor activities of the $\alpha_{1}, \beta_{1}$ and $\beta_{2}$ components were determined in male $\mathrm{BDF}_{1}$ mice against P388 leukemia and B16 melanoma. The results are summarized in Table 6. These agents exhibited activity against both tumors; however $\alpha_{1}$ and $\beta_{2}$ were significantly more potent than $\beta_{1}$.

Table 3. Physiological reactions of LL-D49194.

\begin{tabular}{|c|c|c|c|}
\hline Medium & $\begin{array}{l}\text { Incuba- } \\
\text { tion } \\
\text { period } \\
\text { (days) }\end{array}$ & $\begin{array}{c}\text { Amount } \\
\text { of } \\
\text { growth }\end{array}$ & $\begin{array}{l}\text { Physiological } \\
\text { reaction }\end{array}$ \\
\hline \multirow{2}{*}{$\begin{array}{l}\text { Peptone - } \\
\text { iron agar }\end{array}$} & 7 & Good & No blackening \\
\hline & 14 & Good & No blackening \\
\hline Tyrosine & 7 & Good & No blackening \\
\hline agar & 14 & Good & No blackening \\
\hline Litmus & 7 & Good & Slight proteolysis \\
\hline milk & 14 & Good & $\begin{array}{l}\text { Moderate } \\
\text { proteolysis }\end{array}$ \\
\hline \multirow{2}{*}{$\begin{array}{l}\text { Nutrient } \\
\text { gelatin }\end{array}$} & 7 & Good & No proteolysis \\
\hline & 14 & Good & No proteolysis \\
\hline $\begin{array}{l}\text { Nitrate } \\
\text { broth }\end{array}$ & 7 & Good & Reduction \\
\hline
\end{tabular}

Table 4. Carbon source utilization of LL-D49194.

\begin{tabular}{lc}
\hline Carbon source & Utilization \\
\hline Arabinose & ++ \\
Fructose & +++ \\
Galactose & +++ \\
Glucose & ++ \\
Inositol & +++ \\
Mannitol & ++ \\
Raffinose & + \\
Rhamnose & +++ \\
Salicin & ++ \\
Sucrose & ++ \\
Xylose & +++ \\
\hline
\end{tabular}

+ : Poor utilization, ++ : fair utilization, +++ : good utilization.

Fig. 2. Fermentation profile of culture LL-D49194.

- $\alpha_{1}, \circ \beta_{2}, \square$ growth, $\triangle \mathrm{pH}$.
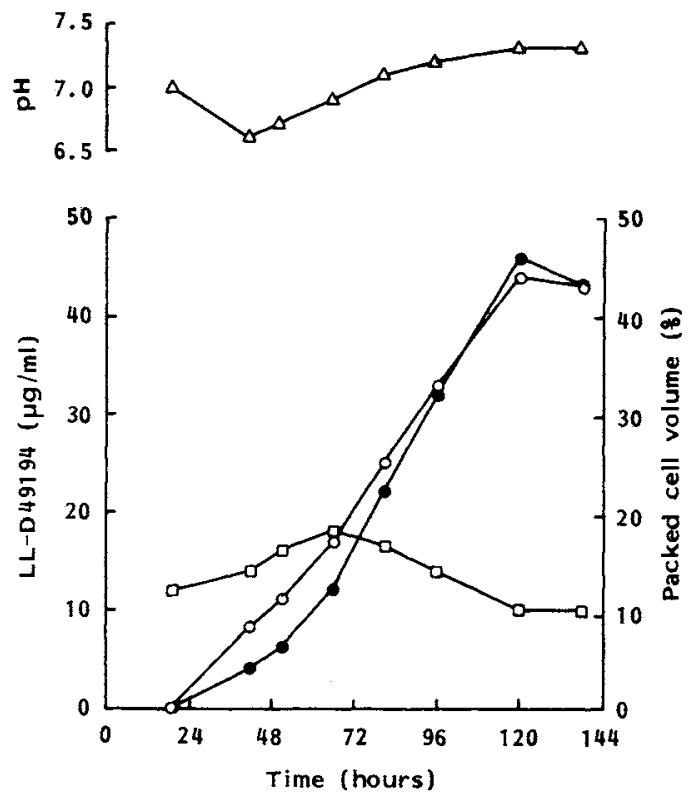

Table 5. In vitro antibacterial activity of LL-D49194 $\alpha_{1}$, $\beta_{1}$ and $\beta_{2}$.

\begin{tabular}{lccc}
\hline \multicolumn{1}{c}{ Organism } & \multicolumn{3}{c}{ MIC $(\mu \mathrm{g} / \mathrm{ml})$} \\
\cline { 2 - 4 } & \multicolumn{1}{c}{$\alpha_{1}$} & $\beta_{1}$ & $\beta_{2}$ \\
\hline Gram-negative bacteria: & & & \\
Escherichia coli Stfd-79-20 & $>128$ & $>128$ & $>128$ \\
E. coli No. 311 & $>128$ & $>128$ & $>128$ \\
Klebsiella pneumoniae AD & $>128$ & $>128$ & $>128$ \\
Acinetobacter calcoaceticus & $>128$ & $>128$ & $>128$ \\
$\quad$ K-77-1 & & & \\
Pseudomonas aeruginosa & $>128$ & $>128$ & $>128$ \\
$\quad$ SSC-78-13 & & & \\
$P$. aeruginosa 12-4-4 & $>128$ & $>128$ & $>128$ \\
P. aeruginosa ATCC 27853 & $>128$ & $>128$ & $>128$ \\
Gram-positive bacteria: & & & \\
Staphylococcus aureus & 1 & 512 & 2 \\
$\quad$ SSC-79-18 & & & \\
S. aureus Smith & 0.5 & 512 & 1 \\
S. aureus ATCC 25923 & 2 & 512 & 8 \\
Micrococcus luteus & $0.5>512$ & 1 \\
$\quad$ PCI 1001 & & & \\
Enterococcus sp. OSU-75-1 & 2 & $>512$ & 8 \\
Enterococcus sp. SSC-81-1 & 2 & $>512$ & 4 \\
Bacillus subtilis ATCC 6633 & $0.5>512$ & 0.5 \\
\hline
\end{tabular}


Table 6. Antitumor activity of LL-D49194 against P388 leukemia and B16 melanoma in mice.

\begin{tabular}{|c|c|c|c|c|c|c|c|}
\hline Compound & $\begin{array}{c}\text { Dose } \\
(\mathrm{mg} / \mathrm{kg})\end{array}$ & $\begin{array}{c}\text { Median } \\
\text { survival } \\
\text { (days) }^{\mathrm{a}}\end{array}$ & $\begin{array}{c}\mathrm{T} / \mathrm{C} \times 100 \\
(\%)\end{array}$ & Compound & $\begin{array}{c}\text { Dose } \\
(\mathrm{mg} / \mathrm{kg})\end{array}$ & $\begin{array}{c}\text { Median } \\
\text { survival } \\
\left(\text { days) }^{\mathbf{a}}\right.\end{array}$ & $\begin{array}{c}\mathrm{T} / \mathrm{C} \times 100 \\
(\%)\end{array}$ \\
\hline \multirow{5}{*}{$\begin{array}{l}\text { P388 Leukemiab: } \\
\text { LL-D49194 } \alpha_{1}\end{array}$} & & & & \multicolumn{4}{|l|}{ B16 Melanomac: } \\
\hline & 0.5 & 18.5 & 156 & \multirow{4}{*}{ LL-D49194 $\alpha_{1}$} & 0.25 & 31.5 & 153 \\
\hline & 0.25 & 19.0 & 165 & & 0.125 & 35.0 & 171 \\
\hline & 0.125 & 16.5 & 144 & & 0.06 & 34.0 & 165 \\
\hline & 0.06 & 16 & 144 & & 0.03 & 27.0 & 132 \\
\hline \multirow{5}{*}{ LL-D49194 $\beta_{1}$} & 400 & 20.5 & 178 & \multirow{3}{*}{ LL-D49194 $\beta_{1}$} & 200 & 45.0 & 219 \\
\hline & 200 & 19.0 & 165 & & 100 & 34.5 & 168 \\
\hline & 100 & 19.5 & 169 & & 50 & 36.5 & 178 \\
\hline & 50 & 18.0 & 156 & \multirow[t]{4}{*}{ LL-D49194 $\beta_{2}$} & 0.5 & 36.0 & 176 \\
\hline & 25 & 16.0 & 139 & & 0.25 & 35.5 & 173 \\
\hline \multirow[t]{3}{*}{ LL-D49194 $\beta_{2}$} & 2 & 16.5 & 143 & & 0.125 & 35.0 & 170 \\
\hline & 1 & 15.5 & 134 & & 0.06 & 27.0 & 131 \\
\hline & 0.5 & 13.0 & 113 & Cisplatin & 0.5 & 27.0 & 131 \\
\hline \multirow[t]{3}{*}{ Cisplatin } & 1.5 & 21.0 & 182 & & 0.25 & 27.5 & 134 \\
\hline & 0.8 & 19.5 & 170 & & 0.125 & 23.5 & 114 \\
\hline & 0.4 & 15.0 & 130 & Control & 0 & 20.5 & 100 \\
\hline Control & 0 & 11.5 & 100 & & & & \\
\hline
\end{tabular}

a Median survival time.

b 30 days for P388.

c 60 days for $\mathrm{B} 16$.

\section{Discussion}

A novel complex of antitumor antibiotics, designated LL-D49194, was isolated from the fermentation broth of an actinomycete, $S$. vinaceus-drappus. The $\alpha_{1}$ and $\beta_{2}$ components were active against Gram-positive bacteria and exerted antitumor effects against both P388 leukemia and B16 melanoma in mice. The $\beta_{1}$ component was inactive against the test bacteria; however, it did possess antitumor activity. Preliminary studies indicate that the antitumor effect of $\alpha_{1}$ is related to its ability to bind to and damage DNA ${ }^{8)}$. The LL-D49194 family of antitumor antibiotics are related structurally to but are distinct from the trioxacarcins produced by Streptomyces bottropensis ${ }^{9,10}$.

\section{Acknowledgments}

The authors are grateful to the personnel of the Microbial Chemistry, Antimicrobial Chemotherapy, and Chemotherapy Research Departments for their contributions and helpful suggestions.

\section{References}

1) Shirling, E. B. \& D. Gotrlieb: Methods for characterization of Streptomyces species. Int. J. Syst. Bacteriol. 16: $313 \sim 340,1966$

2) Gordon, R. E.; S. K. Mishra \& D. A. Barnett: Some bits and pieces of the genus Nocardia: $N$. carnea, $N$. vaccinii, $N$. transvalensis, $N$. orientalis and $N$. aerocolonigenes. J. Gen. Microbiol. 109: 69 78, 1978

3) LecheValier, M. P. \& H. A. Lechevalier: The chemotaxonomy of actinomycetes. In Actinomycete Taxonomy. No. 6. Eds, A. Dietz \& D. W. Thayer, pp. 227 291, Soc. for Ind. Micro. Special Publication, 1980

4) Elespuru, R. K. \& M. B. Yarmolinsky: A colorimetric assay of lysogenic induction designed for screening potential carcinogenic and carcinostatic agents. Environ. Mutagen. 1: 55 78, 1979

5) Elespuru, R. K. \& R. J. White: Biochemical prophage induction assay: A rapid test for antitumor agents that interact with DNA. Cancer Res. 43: $2819 \sim 2830,1983$

6) LeE, M. D.; J. C. JaMes, M. Hertz, G. O. Morton, W. J. MCGahren, M. Siegel \& D. B. Borders: LL-D49194 antibiotics, a complex of new antitumor agents: isolation and structure determination. Program and Abstracts of the 24th Intersci. Conf. on Antimicrob. Agents Chemother., No. 1146, p. 293, Washington, D.C., Oct. $8 \sim 10,1984$

7) Lechevalier, H. A.; M. P. Lechevalier \& N. N. Gerber: Chemical composition as a criterion in the classification 
of actinomycetes. Adv. Appl. Microbiol. 14: 47 72, 1971

8) Greenstein, M.; M. J. Mroczenski-Wildey, G. Peterson \& W. M. Maiese: LL-D49194 antibiotics, a complex of new antitumor agents: Mechanism of action. Program and Abstracts of the 25th Intersci. Conf. on Antimicrob. Agents Chemother., No. 236, p. 134, Minneapolis, Sept. $29 \sim$ Oct. 2, 1985

9) Tomita, F.; T. Tamaok1, M. Morimoto \& K. Fujimoto: Trioxacarcins, novel antitumor antibiotics. I. Producing organism, fermentation and biological activities. J. Antibiotics 34: 1519 1524, 1981

10) Tamaoki, T.; K. Shirahata, T. Ima \& F. Tomita: Trioxacarcins, novel antitumor antibiotics. II. Isolation, physico-chemical properties and mode of action. J. Antibiotics $34: 1525 \sim 1530,1981$ 